\title{
Quantitative Genetics Validates Previous Genetic Variants and Identifies Novel Genetic Players Influencing Alzheimer's Disease Cerebrospinal Fluid Biomarkers
}

Mafalda Ramos de Matos $^{\mathrm{a}, 1}$, Catarina Ferreira ${ }^{\mathrm{a}, 1}$, Sanna-Kaisa Herukka ${ }^{\mathrm{b}}$, Hilkka Soininen ${ }^{\mathrm{b}}$, André Janeiro $^{\mathrm{a}}$, Isabel Santana ${ }^{\mathrm{c}}$, Inês Baldeiras ${ }^{\mathrm{c}}$, Maria Rosário Almeida ${ }^{\mathrm{c}}$, Alberto Lleód ${ }^{\mathrm{d}}$, Oriol Dols-Icardo ${ }^{\mathrm{d}}$, Daniel Alcolea ${ }^{\mathrm{d}}$, Luisa Benussi ${ }^{\mathrm{e}}$, Giuliano Binetti ${ }^{\mathrm{f}}$, Anna Paterlini ${ }^{\mathrm{e}}$, Roberta Ghidoni $^{\mathrm{e}}$, Benedetta Nacmias ${ }^{\mathrm{g}}$, Olga Meulenbroek ${ }^{\mathrm{h}}$, Linda J.C. van Waalwijk van Doorn ${ }^{\mathrm{i}}$, H. Bea Kuiperij ${ }^{i}$, Lucrezia Hausner ${ }^{\mathrm{j}}$, Gunhild Waldemar ${ }^{\mathrm{k}}$, Anja Hviid Simonsen ${ }^{\mathrm{k}}$, Magda Tsolaki ${ }^{\mathrm{l}}$, Olymbia Gkatzima $^{\mathrm{m}}$, Catarina Resende de Oliveira ${ }^{\mathrm{c}}$, Marcel M. Verbeek ${ }^{\mathrm{i}}$, Jordi Clarimon ${ }^{\mathrm{d}}$, Mikko Hiltunen $^{\mathrm{n}}$, Alexandre de Mendonça ${ }^{\mathrm{a}}$ and Madalena Martins ${ }^{\mathrm{a}, *}$

${ }^{a}$ Instituto de Medicina Molecular, Faculdade de Medicina, Universidade de Lisboa, Lisboa, Portugal

${ }^{\mathrm{b}}$ Institute of Clinical Medicine - Neurology, University of Eastern Finland, and Department of Neurology, Kuopio University Hospital, Kuopio, Finland

${ }^{\mathrm{c}}$ Neurochemistry Laboratory, CHUC - Centro Hospitalar e Universitário de Coimbra, Neurogenetics Laboratory, CNC - Center for Neuroscience and Cell Biology and CNC.IBILI, Faculty of Medicine, University of Coimbra, Portugal

${ }^{\mathrm{d}}$ Department of Neurology and Sant Pau Biomedical Research Institute, Memory Unit, Hospital de la Santa Creu $i$ Sant Pau, Autonomous University of Barcelona, Barcelona, Spain, and Centro de Investigación Biomédica en Red en enfermedades Neurodegenerativas, CIBERNED, Madrid, Spain

${ }^{\mathrm{e}}$ Molecular Markers Laboratory, IRCCS Cento S. Giovanni di Dio Fatebenefratelli, Brescia, Italy

${ }^{\mathrm{f}}$ Molecular Markers Laboratory and MAC Memory Clinic, IRCCS Cento S. Giovanni di Dio Fatebenefratelli, Brescia, Italy

$\mathrm{g}^{\mathrm{g}}$ Department of Neuroscience, Psychology, Drug Research and Child Health, University of Florence, Florence, Italy

${ }^{\mathrm{h}}$ Department of Geriatrics, Radboud University Medical Center, Donders institute for Brain, Cognition and Behaviour, Radboud Alzheimer Center, Nijmegen, The Netherlands

\footnotetext{
${ }^{1}$ These authors contributed equally to this work.

*Correspondence to: Madalena Martins, PhD, Instituto de Medicina Molecular, Av. Professor Egas Moniz, Edifício Egas Moniz, P1C74, 1649-028 Lisboa, Portugal. Tel.: +35 1 217999411/Ext. 47149; Fax: +35 1 217999412; E-mail: mcmartins227@gmail.com. and Instituto de Tecnologia Química e Biológica António Xavier, Universidade NOVA de Lisboa
}

ITQB NOVA, Av. da República, 2780-157 Oeiras, Portugal. Tel.: +35 1 214469250; Fax: +35 1 214411277; E-mail: madalena.martins@itqb.unl.pt. 
${ }^{\mathrm{i}}$ Department of Neurology, Department of Laboratory Medicine, Radboud University Medical Centre, Donders institute for Brain, Cognition and Behaviour, Radboud Alzheimer Center, Nijmegen, The Netherlands

${ }^{\mathrm{j}}$ Department Geriatric Psychiatry (CIMH), Medical Faculty Mannheim, Heidelberg University, Mannheim, Germany

${ }^{\mathrm{k}}$ Department of Neurology, Danish Dementia Research Centre, Rigshospitalet, University of Copenhagen, Denmark

${ }^{1}$ 1st Department of Neurology, Aristotle University of Thessaloniki, Makedonia, Greece and Greek Alzheimer Association, Greece

${ }^{\mathrm{m}}$ Greek Association of Alzheimer's Disease and Related Disorders “Alzheimer Hellas”, Greece

${ }^{\mathrm{n}}$ Institute of Biomedicine, University of Eastern Finland, Kuopio, Finland

Accepted 23 August 2018

\begin{abstract}
Cerebrospinal fluid (CSF) biomarkers have been extensively investigated in the Alzheimer's disease (AD) field, and are now being applied in clinical practice. CSF amyloid-beta $\left(\mathrm{A} \beta_{1-42}\right)$, total tau (t-tau), and phosphorylated tau (p-tau) reflect disease pathology, and may be used as quantitative traits for genetic analyses, fostering the identification of new genetic factors and the proposal of novel biological pathways of the disease. In patients, the concentration of CSF A $\beta_{1-42}$ is decreased due to the accumulation of $A \beta_{1-42}$ in amyloid plaques in the brain, while t-tau and p-tau levels are increased, indicating the extent of neuronal damage. To better understand the biological mechanisms underlying the regulation of AD biomarkers, and its relation to $\mathrm{AD}$, we examined the association between 36 selected single nucleotide polymorphisms (SNPs) and $\mathrm{AD}$ biomarkers $A \beta_{1-42}, t$-tau, and p-tau in CSF in a cohort of 672 samples (571 AD patients and 101 controls) collected within ten European consortium centers.

Our results highlighted five genes, APOE, LOC100129500, PVRL2, SNAR-I, and TOMM40, previously described as main players in the regulation of CSF biomarkers levels, further reinforcing a role for these in AD pathogenesis. Three new AD susceptibility loci, INPP5D, CD2AP, and CASS4, showed specific association with CSF tau biomarkers. The identification of genes that specifically influence tau biomarkers point out to mechanisms, independent of amyloid processing, but in turn related to tau biology that may open new venues to be explored for $\mathrm{AD}$ treatment.
\end{abstract}

Keywords: Alzheimer's disease, cerebrospinal fluid biomarkers, endophenotypes, European multicenter study, quantitative trait loci

\section{INTRODUCTION}

Alzheimer's disease (AD) is the most common form of dementia associated to aging and involving a complex interaction between genetic and environmental risk factors. The burden of $\mathrm{AD}$ dementia is substantial and diagnosis and treatment options remain limited, so the identification and validation of new biological pathways associated with pathology are needed. $\mathrm{AD}$ is characterized by the presence of extracellular $A \beta$ plaques and intracellular aggregates of hyperphosphorylated tau in the brain [1]. Cerebrospinal fluid (CSF) amyloid-beta 1-42 (A $\left.\beta_{1-42}\right)$, total tau (t-tau), and phosphorylated tau ( $\mathrm{p}$-tau) are established biomarkers for $\mathrm{AD}$, and have been used as quantitative traits for genetic analyses. In patients with $\mathrm{AD}$, the concentration of CSF $A \beta_{1-42}$ is decreased, reflecting the sequestration of $A \beta_{1-42}$ in amyloid plaques in the brain [2]. Conversely, ttau and p-tau levels in CSF are increased [3] with CSF t-tau levels directly correlated with the number of neurofibrillary tangles and the load of hyperphosphorylated tau present in the brain. Elevated CSF $\mathrm{t}$-tau and p-tau levels are indicators of neuronal loss, and p-tau levels have been shown to predict cognitive decline and conversion to $\mathrm{AD}$ in subjects with mild cognitive impairment (MCI) [4]. Additionally, $\mathrm{t}$-tau/A $\beta_{1-42}$ and $\mathrm{p}$-tau $/ \mathrm{A} \beta_{1-42}$ ratios have been indicated to represent progression/conversion from $\mathrm{MCI}$ to $\mathrm{AD}[5]$.

$\mathrm{AD}$ has a strong genetic component, a portion of which is explained by the apolipoprotein $\mathrm{E}$ ( $A P O E)$ $\varepsilon 4$ allele and several other genes identified by candidate gene studies, genome-wide association studies (GWAS) and meta-analysis [6-10]. The top 10 $\mathrm{AD}$ risk variants identified, and listed in the AlzGene database, include APOE $E_{\varepsilon 2 / 3 / 4}, B I N 1, C L U$, ABCA7, CR1, PICALM, MS4A6A, CD33, MS4A4E, and $C D 2 A P$ (http://www.alzgene.org/). Further, 11 new $\mathrm{AD}$ variants with genome-wide significance $\left(p\right.$-value $\left.<5 \times 10^{-8}\right)$ were highlighted in 2013 , in the largest meta-analysis performed to date with 
74,046 samples [10]. Notably, most of these large well-powered genetic studies have been restricted to binary categories, such as clinical diagnosis. Quantitative traits, that provide higher power than regular case-control analyses, are now being increasingly used and have already successfully identified new genetic factors implicated in several diseases [11]. AD biomarkers that reflect disease pathology, namely CSF t-tau, $p$-tau, and $A \beta_{1-42}$ have in the last years started to be used as quantitative traits for genetic analyses [11-16]. This approach is of outmost importance since, besides a higher power to identify new genetic factors, it can provide novel underlying biological models of disease, associated with specific processes and pathways, ultimately pinpointing new potential therapeutic targets. It has been shown that genetic variants that increase risk for AD modify CSF $\mathrm{A} \beta_{1-42}$ and tau levels. APP, PSEN1, PSEN2, and the common variants in $A P O E$ were previously found to have a genome-wide significant association with CSF $\mathrm{A} \beta_{1-42}$ and tau levels in different studies $[11,14,16$, 17]. In 2013, the second largest GWAS performed to date $(n=1269)$, detected four independent genomewide significant loci associated with CSF t-tau and p-tau, including, apart from APOE, SNAR-I, GLIS3 and within the TREM gene cluster [11]. Recently, a new GWAS, from the same team, performed in an extended population $(n=3,146)$, resulted in five genome-wide significant loci, three repeating the results from the previous study (APOE, SNAR-I, and GLIS3) and two novel loci, associated again with p-tau (within PCDH8 and CTDP1) [16]. Another GWAS in a smaller population $(n=374)$ detected four single nucleotide polymorphisms (SNPs) in the regions of the APOE, LOC100129500, TOMM40, and EPC2 genes that reached genome-wide significance for associations with one or more CSF biomarkers [14]. Nonetheless, the majority of quantitative trait loci (QTL) studies published have been conducted in much smaller cohorts showing robust associations with SNPs surrounding APOE on chromosome 19, but failing to replicate most of the additional genome-wide associations. New studies, in different populations, are needed to consolidate the knowledge on the relation between these AD risk genes and $\mathrm{AD}$ biomarkers.

The main goal of the present study was to further clarify the association of specific genetic variants with AD biomarkers. With this aim, we used a quantitative traits genetics approach including 36 top SNPs, selected from previous studies on CSF biomarkers and $\mathrm{AD}$ genetic variants, for association with $\mathrm{CSF}$ levels of t-tau, p-tau, and $A \beta_{1-42}$. Here, we used an independent European multicenter cohort, the third largest to date with 672 samples, using similar methodologies between centers, and have successfully contributed to decipher previous inconsistencies between AD genetic variants and AD CSF biomarkers, and further pinpoint pathways and biological mechanisms underlying $\mathrm{AD}$.

\section{METHODS}

\section{Study population}

This multicenter study was performed within the BIOMARKAPD consortium (http://www.neuro degenerationresearch.eu/initiatives/annual-calls-forproposals/closed-calls/biomarkers-transnationalcall/results-of-biomarker-call/biomarkapd/), gather ing 10 research centers from eight European countries. The initial dataset used comprised 700 samples from $595 \mathrm{AD}$ patients and 105 controls (including healthy and subjective memory complaints subjects) (Table 1) coming from: Instituto de Medicina Molecular, Faculty of Medicine, University of Lisbon, Portugal; Institute of Clinical Medicine and Institute of Biomedicine, University of Eastern Finland, Kuopio, Finland; CHUC - Centro Hospitalar e Universitário de Coimbra, Portugal; Memory Unit, Neurology Department and Sant Pau Biomedical Research Institute, Hospital de la Santa Creu i Sant Pau, Autonomous University of Barcelona, Barcelona, Spain, and Centro de Investigación Biomédica en Red en enfermedades Neurodegenerativas, CIBERNED, Madrid, Spain; MAC Memory Center and Molecular Markers Laboratory, IRCCS Cento S. Giovanni di Dio Fatebenefratelli, Brescia, Italy; Department of Neuroscience, Psychology, Drug Research and Child Health, University of Florence, Italy; Radboud University Medical Centre, Radboud Alzheimer Center, Nijmegen, The Netherlands; Department Geriatric Psychiatry (CIMH), Medical Faculty Mannheim, Heidelberg University, Mannheim, Germany; Danish Dementia Research Centre, Department of Neurology, Rigshospitalet, University of Copenhagen, Denmark; 1st Department of Neurology, Aristotle University of Thessaloniki, Makedonia, Greek Alzheimer Association and Greek Association of Alzheimer's Disease and Related Disorders “Alzheimer Hellas", Greece.

Patients were evaluated by neurologists with longstanding expertise in dementia, and all were subjected 
Table 1

Summary of sample characteristics for the Center(s) in each country and for all Centers

\begin{tabular}{|c|c|c|c|c|c|c|c|c|c|}
\hline & Denmark & Finland & Germany & Greece & Italy & Portugal & Spain & The Netherlands & All Centers \\
\hline \multicolumn{10}{|l|}{ All samples } \\
\hline $\mathrm{N}$ & 29 & 237 & 49 & 25 & 79 & 118 & 92 & 43 & 672 \\
\hline Age $(y) ;$ mean \pm SD & $67 \pm 8$ & $72 \pm 7$ & $71 \pm 9$ & $75 \pm 8$ & $69 \pm 9$ & $64 \pm 9$ & $67 \pm 10$ & $72 \pm 8$ & $69 \pm 9$ \\
\hline APOE $\varepsilon 4+(\%)$ & 45 & 69 & 35 & 24 & 50 & 43 & 42 & 63 & 53 \\
\hline Male (\%) & 52 & 34 & 41 & 52 & 33 & 32 & 38 & 40 & 36 \\
\hline p-tau level, pg/ml & $60 \pm 31$ & $80 \pm 34$ & $81 \pm 48$ & $53 \pm 22$ & $74 \pm 33$ & $74 \pm 41$ & $69 \pm 35$ & $9 \pm 4$ & $76 \pm 39$ \\
\hline $\mathrm{t}$-tau level, pg/ml & $350 \pm 191$ & $501 \pm 261$ & $397 \pm 300$ & $348 \pm 230$ & $524 \pm 283$ & $583 \pm 337$ & $508 \pm 364$ & $48 \pm 3$ & $480 \pm 265$ \\
\hline $\begin{array}{l}\mathrm{A} \beta_{1-42} \text { level, } \mathrm{pg} / \mathrm{ml} \\
\text { Controls }\end{array}$ & $499 \pm 348$ & $490 \pm 197$ & $717 \pm 244$ & $352 \pm 172$ & $427 \pm 198$ & $474 \pm 198$ & $516 \pm 250$ & $450 \pm 167$ & $488 \pm 220$ \\
\hline $\mathrm{N}$ & 11 & 29 & 18 & - & 11 & - & 32 & & 101 \\
\hline Age $(y) ;$ mean \pm SD & $65 \pm 10$ & $67 \pm 7$ & $66 \pm 9$ & - & $66 \pm 10$ & - & $60 \pm 9$ & & $65 \pm 9$ \\
\hline APOE $\varepsilon 4+(\%)$ & 27 & 17 & 28 & - & 27 & - & 22 & & 23 \\
\hline Male (\%) & 55 & 34 & 61 & - & 27 & - & 31 & 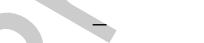 & 40 \\
\hline p-tau level, pg/ml & $49 \pm 21$ & $59 \pm 17$ & $41 \pm 11$ & - & $45 \pm 12$ & - & $41 \pm 14$ & - & $48 \pm 17$ \\
\hline t-tau level, $\mathrm{pg} / \mathrm{ml}$ & $172 \pm 102$ & $274 \pm 103$ & $169 \pm 64$ & - & $212 \pm 80$ & - & $236 \pm 86$ & - & $263 \pm 99$ \\
\hline $\begin{array}{l}\mathrm{A} \beta 1-42 \text { level, } \mathrm{pg} / \mathrm{ml} \\
\text { Alzheimer's disease }\end{array}$ & $911 \pm 161$ & $803 \pm 158$ & $786 \pm 238$ & - & $688 \pm 161$ & - & $760 \pm 182$ & - & $791 \pm 184$ \\
\hline $\mathrm{N}$ & 18 & 208 & 3 & 25 & 68 & 118 & 00 & 43 & 571 \\
\hline Age $(y) ;$ mean \pm SD & $68 \pm 5$ & $73 \pm 7$ & $74 \pm 8$ & $75 \pm 8$ & $70 \pm 8$ & $63 \pm 9$ & $71 \pm 8$ & $72 \pm 8$ & $70 \pm 9$ \\
\hline APOE $\varepsilon 4+(\%)$ & 56 & 76 & 39 & 24 & 53 & 43 & 53 & 63 & 58 \\
\hline Male (\%) & 50 & 34 & 29 & 52 & 34 & 32 & 42 & 40 & 36 \\
\hline p-tau level, & $66 \pm 34$ & $84 \pm 35$ & $97 \pm 47$ & $53 \pm 28$ & $79 \pm 33$ & $74 \pm 41$ & $84 \pm 34$ & $99 \pm 41$ & $81 \pm 40$ \\
\hline t-tau level, & $374 \pm 223$ & $545 \pm 260$ & $492 \pm 308$ & $348 \pm 230$ & $575 \pm 271$ & $583 \pm 337$ & $644 \pm 373$ & $648 \pm 383$ & $525 \pm 263$ \\
\hline $\mathrm{A} \beta_{1-42}$ level, pg/ml & $247 \pm 109$ & $446 \pm 159$ & $673 \pm 238$ & $352 \pm 172$ & $385 \pm 169$ & $474 \pm 198$ & $386 \pm 171$ & $450 \pm 167$ & $433 \pm 178$ \\
\hline
\end{tabular}

Age at the lumbar puncture in years with the mean and the standard deviation; percentage of APOE $\varepsilon 4+$ allele carriers; percentage of males. For each biomarker the mean in $\mathrm{pg} / \mathrm{ml}$ with the standard deviation is shown.

to clinical history and neurological examination. Diagnosis of $\mathrm{AD}$ was made in accordance to the guidelines of the National Institute of Neurological Disorders and Stroke and Alzheimer's Disease and Related Disorders Association (NINCDS-ADRDA) and of the National Institute on Aging-Alzheimer's Association [18, 19]. Demographic and clinical characteristics of the study participants were obtained by medical interview at the time of CSF and blood sampling as well as inspection of medical records. The Mann-Whitney Rank test was applied for comparison of age differences between cases and control subjects, and the Fisher exact test was used to evaluate difference of proportions in gender between cases and control subjects. Cases are significantly older than control subjects $(p<0.001)$ and there was a significant difference in the distribution of gender between cases and control subjects $(p=0.001)$, hence all statistical analyses were adjusted for age and gender.

The BIOMARKAPD project was approved by the ethical committees of the participating centers, and all participants or their legal representatives signed a written informed consent form in accordance with the Declaration of Helsinki.

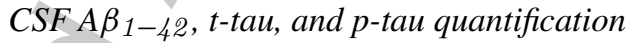

Quantification of biomarkers was done locally in each center. To reduce any possible heterogeneity, CSF levels of $A \beta_{1-42}$, t-tau, and p-tau were measured using the same type of platform (regular ELISA) and the same commercially available enzyme-linked immunosorbent assays INNOTEST $^{\circledR} \beta$-amyloid (1-42), Innotest hTau Ag, and Innotest Phospho-tau (181P) (Innogenetics, Ghent, Belgium) at all centers. Biomarkers quantification was performed according to manufacturer's instructions by experienced laboratory technicians. Before any analysis, raw values of CSF levels were $\operatorname{lof}_{10}$-transformed to approximate a normal distribution.

To reduce the potential influence of extreme outliers, GraphPad Pris $6^{\circledR}$ (GraphPad Software Inc., La Jolla, CA) software was used to identify the CSF quantification outliers by ROUT method and 20 extreme outliers were removed from the analysis. PASW Statistics $21.0^{\circledR}$ (SPSS Inc.) software was used to perform the univariate analysis of variance of CSF biochemical data, adjusted for age and gender (ANCOVA). 


\section{SNP selection}

Individual samples were genotyped for the most meaningful SNPs, previously found to be associated with $\mathrm{AD}$ and/or with CSF $\mathrm{A} \beta_{1-42}$, p-tau and $\mathrm{t}$-tau biomarkers. SNPs were selected according the following criteria: 1) the top SNPs found to be associated with AD: The top 10 SNPs in AlzGene (an online database providing meta-analysis of published $\mathrm{AD}$ and genetic association studies, for AlzGene top results criteria, see [20]); and the top 4 SNPs from the largest and most recent $\mathrm{AD}$ meta-analysis carried out so far, with 74,046 individuals (reaching GWAS significance in the combined discovery and replication dataset [10]) (Supplementary Table 1). 2) The top SNPs found to be associated with CSF $\mathrm{A} \beta_{1-42}$, $\mathrm{t}$-tau, and/or p-tau biomarkers in two of the largest GWAS performed to date: The 17 SNPs highlighted in the study of Cruchaga et al., a GWAS for CSF t-tau and p-tau levels [11]; and the 9 SNPs highlighted in Kim et al., a GWAS study of the CSF biomarkers $A \beta_{1-42}$, t-tau, p-tau, p-tau/A $\beta_{1-42}$, and t-tau/A $\beta_{1-42}[14]$. Following this prioritization approach-selection of the most significantly associated SNPS with AD and/or CSF biomarkers, from major studies (larger datasets, more representative and statistically significant)—40 SNPs were selected (14 SNPs found associated to AD and 26 SNPs associated to AD CSF biomarkers). Since two SNPs were common between two studies (rs429358 from Kim et al. [14] and AlzGene [20]; and rs2075650 from Cruchaga et al. [11] and Kim et al. [14]), the final number of selected SNPs was 38. Individual samples were genotyped for these 38 SNPs (Supplementary Table 1).

\section{Genotyping}

DNA was extracted using QIAamp DNA Blood Maxi kits (Qiagen, Germantown, MD, USA) or an available salting out procedure whenever appropriate and diluted in Tris-EDTA (TE) buffer. The concentrations of extracted DNA were determined by Nanodrop (NanoDrop Technologies, Wilmington, $\mathrm{DE})$.

A total of 38 selected SNPs were genotyped using the Sequenom's iPlex assay (Sequenom, San Diego, CA, USA) and the Sequenom MassArray K2 platform according to the manufacturer's protocol. Samples from nine centers were genotyped by the Lisbon Centre (480 samples; at the Genomics Unit of the Instituto Gulbenkian de Ciência). AD samples from Kuopio Centre were genotyped locally (220 samples).

Extensive quality control was performed using eight HapMap (http://hapmap.ncbi.nlm.nih.gov/) controls of diverse ethnicity, Hardy-Weinberg equilibrium (HWE) with $p<0.001$, and a minimum of $95 \%$ call rate for each SNP. Genotype determinations were performed blinded to affection status. Two SNPs did not meet the quality control criteria (rs12972970 and rs59860681) and were excluded. Twenty-eight samples ( 24 patients and 4 controls) with $<90 \%$ call rate or corresponding to duplicates were excluded from analysis.

\section{Quantitative trait loci}

A total of 36 SNPs, that overpassed quality control, were used in the QTL analysis. The final dataset consisted of 672 subjects comprising 571 patients and 101 controls. The QTL analysis was performed to assess the main effect of each tested SNP on CSF biomarkers levels $\left(\mathrm{A} \beta_{1-42}, \mathrm{t}\right.$-tau, $\mathrm{p}$-tau, $\mathrm{t}$-tau $/ \mathrm{A} \beta_{1-42}$ and $p$-tau/A $\left.\beta_{1-42}\right)$. At each SNP, CSF biomarkers levels were regressed onto genotype counts in a regression model that included affection status, gender, age, and collection site as covariates. A second stage of QTL analysis was performed which included the $A P O E$ genotype as a fifth covariate. $A \beta_{1-42}, \mathrm{t}$-tau, $\mathrm{p}$-tau, t-tau $/ \mathrm{A} \beta_{1-42}$, and $\mathrm{p}$-tau $/ \mathrm{A} \beta_{1-42}$ were $\log _{10^{-}}$ transformed to approximate a normal distribution before QTL analysis. SNPassoc ${ }^{\circledR}$ v.1.4-9 package [21] implemented in the $\mathrm{R}$ freeware (http://cran.rproject.org/) was used for logistic regression analysis. Results were considered significant below the conventional level of 0.05 . Bonferroni corrections for multiple tests were carried out to exclude type I errors (the significance level for 36 tests is set at $p$-value $<1.39 \times 10^{-3}$ ).

\section{RESULTS}

Variability in CSF $A \beta_{1-42}, t$-tau, and p-tau levels and association to common variants

We evaluated a final set of 36 selected SNPs for association with the CSF levels of $A \beta_{1-42}$, t-tau and p-tau in a large population of 672 unrelated European individuals. In this study, we followed a standardized quantification methodology to measure the CSF levels of $A \beta_{1-42}$, t-tau and p-tau at the 10 participating centers and performed stringent quality control (QC) in both the genotype and the phenotype data 
previously to any analysis. While there are differences in the absolute levels of the biomarker measurements between the different centers, reflecting differences within the parameters reported by the analytical protocol QC, the CSF $\mathrm{A} \beta_{1-42}$, $\mathrm{t}$-tau, and p-tau levels show similar characteristics (Table 1). CSF A $\beta_{1-42}$, t-tau, and p-tau levels are normally distributed after log transformation and show a 6- to 16-fold difference between AD patients and control samples (in the centers that contained both types of samples). As expected we obtained lower values of $A \beta_{1-42}$ and higher values of $t$-tau and $p$-tau levels in $\mathrm{AD}$ patients as compared to controls, either at each center or when looking at the total values for all the centers (Table 1).

\section{Loci associated with CSF A $\beta_{1-42}$ levels}

Ten SNPs in the regions of APOE, TOMM40, PVRL2, and LOC100129500, in chromosome 19, reached significance after Bonferroni adjustment (corrected $p<1.39 \times 10^{-3}$ ) (Table 2). The strongest associations were found within the $A P O E$ gene, as expected, for rs769449 $\left(p=2.57 \times 10^{-14}\right)$ and rs429358 $\left(p=2.03 \times 10^{-17}\right)$. rs429358, that defines $\varepsilon 4$ allele, had the most significant association with CSF $A \beta_{1-42}$, t-tau, and p-tau levels and also with the $\mathrm{t}$-tau $/ \mathrm{A} \beta_{1-42}$ and $\mathrm{p}$-tau/ $\mathrm{A} \beta_{1-42}$ ratios (Fig. 1). Also, several variants in TOMM40 and PVRL2 reached highly significant $p$ values $\left(p<1 \times 10^{-08}\right)$ (Table 2, Fig. 1). All these SNPs were found to be associated with lower levels of $A \beta_{1-42}$, suggestive of a contribution to an increased risk for AD. Nevertheless, when the $A P O E$ genotype was included in the model as covariate, the association for these SNPs became nonsignificant, confirming the strong influence of $A P O E$ on the results (Table 3 ).

\section{Loci associated with CSF t-tau and p-tau levels}

Sixteen SNPs in the regions of APOE, TOMM40, PVRL2, INPP5D, SNAR-I, CD2AP, GLIS3, LOC100129500, and CASS4 were associated with $\mathrm{t}$-tau and/or $\mathrm{p}$-tau levels $(p<0.05)($ Table 2$)$. One to four SNPs in several loci showed highly significant $p$ values $\left(p<1 \times 10^{-05}\right)$, particularly in chromosome 19 with the strongest association observed for APOE (rs429358, $p=1.40 \times 10^{-11}$ and $p=3.18 \times 10^{-8}$, association to t-tau and $\mathrm{p}$-tau levels, respectively) (Table 2, Fig. 1). Similarly to CSF ${\mathrm{A} \beta_{1}{ }^{-}}_{42}$ levels, the strongest associations for CSF t-tau and p-tau, after $A P O E$, were found in four SNPs in TOMM40 and two SNPs in PVRL2 regions $\left(9.10 \times 10^{-07} \leq p \leq 3.21 \times 10^{-4}\right)$, located on chromosome 19 (Table 2, Fig. 1), all overpassing Bonferroni correction. All these SNPs were associated with higher levels of t-tau and p-tau, suggestive of an increased risk for AD. Notwithstanding, when we adjusted the analysis for $A P O E$ genotype (Table 3 ), most of the associations became non-significant implying again a strong influence of $A P O E$ on these results.

Interestingly, four SNPs outside the $A P O E$ region, in INPP 5D, SNAR-I, CD2AP, and CASS4 genes, were associated with CSF t-tau, p-tau, or both $(p<0.05)$ (Table 2), remaining significant (except CD2AP) after adjustment for $A P O E$ genotype (Table 3). Remarkably, these SNPs were not associated with $\mathrm{A} \beta_{1-42}$ levels. While the two SNPs in SNAR-I were associated with higher levels of t-tau and p-tau (indicative of an increased risk for AD), SNPs in INPP5D and CASS4 were associated with lower levels of t-tau and/or p-tau suggestive of a protective role in $\mathrm{AD}$.

\section{SNP association with t-tau/A $\beta_{1-42}$ and $p$-tau/A $\beta_{1-42}$ levels}

In addition to $A \beta_{1-42}$, t-tau and p-tau levels, the ratios t-tau/A $\beta_{1-42}$ and $p$-tau/A $\beta_{1-42}$ have been used to effectively distinguish patients with AD from controls. Twelve SNPs in APOE, TOMM40, PVRL2, LOC100129500, and SNAR-I, were found associated with t-tau/A $\beta_{1-42}$ and/or $\mathrm{p}$-tau/A $\beta_{1-42}$ ratios $(p<0.05)$ (Table 2$)$. Also, in this case, the strongest associations were with the two SNPs in APOE (rs769449 and rs429358; $1.85 \times 10^{-19} \leq p \leq 1.29 \times 10^{-13}$ ), just followed by the high associations in TOMM4O and PVRL2 with $p<1 \times 10^{-08}$ (all overpassing Bonferroni correction), once again reinforcing the importance of these regions in the determination of the levels of AD biomarkers. The association with higher CSF t-tau/A $\beta_{1-42}$ and/or $p$-tau/A $\beta_{1-42}$ ratios further suggests its contribution to an increased risk in AD. All associations but for rs 429358 became non-significant when $A P O E$ genotype was used as covariate in the analysis, further indicating a strong $A P O E$ dependent effect on the levels of the several biomarkers studied.

\section{DISCUSSION}

AD diagnosis has substantially improved over the past decade with CSF biomarkers acquiring an 
Table 2

Significant SNPs for $A \beta_{1-42}$, t-tau, and p-tau levels, and with t-tau/A $\beta_{1-42}$ and p-tau/A $\beta_{1-42}$ ratios (adjusted for affection status, age, gender, and collection site). Significance after Bonferroni adjustment (corrected $p<1.39 \times 10^{-3}$ )

\begin{tabular}{|c|c|c|c|c|c|c|c|c|c|c|c|}
\hline$\overline{\mathrm{Chr}}$ & dbSNP & MAF & Gene & $\begin{array}{l}\text { Reason for SNP } \\
\text { Selection }\end{array}$ & Model & $\begin{array}{c}\text { SNP } \\
\text { Type/Location }\end{array}$ & $A \beta_{1-42}$ & t-tau & p-tau & $\mathrm{t}$-tau/A $\beta_{1-42}$ & $\mathrm{p}-\operatorname{tau} / \mathrm{A} \beta_{1-42}$ \\
\hline 2 & rs35349669 & 0.435 & INPP5 & AD assoc.* & B & Intron & 0.6229 & $3.84 \times 10^{-02} \downarrow$ & 0.4122 & 0.0596 & 0.2959 \\
\hline 3 & rs1316356 & 0.396 & SNAR-I & CSF assoc.* & A & Intergenic & 0.7636 & $1.77 \times 10^{-03} \uparrow$ & $3.26 \times 10^{-03} \uparrow$ & $4.98 \times 10^{-02} \uparrow$ & 0.1176 \\
\hline 3 & rs9877502 & 0.399 & SNAR-I & CSF assoc.* & A & Intergenic & 0.9000 & $2.49 \times 10^{-03} \uparrow$ & $5.48 \times 10^{-03} \uparrow$ & $4.48 \times 10^{-02} \uparrow$ & 0.10848 \\
\hline 6 & rs9349407 & 0.280 & $C D 2 A P$ & AD assoc.* & $\mathrm{C}$ & Intron & 0.6589 & $4.77 \times 10^{-02} \uparrow$ & 0.1488 & 0.2051 & 0.385 \\
\hline 9 & rs514716 & 0.151 & GLIS3 & CSF assoc.* & A & Intron & 0.8136 & $4.88 \times 10^{-02} \uparrow$ & 0.0729 & 0.0996 & 0.24973 \\
\hline 19 & rs12972156 & 0.251 & PVRL2 & CSF assoc.* & $\mathrm{C}$ & Intron & $2.25 \times 10^{-09} \downarrow$ & $8.33 \times 10^{-05} \uparrow$ & $3.21 \times 10^{-04} \uparrow$ & $1.27 \times 10^{-08} \uparrow$ & $5.27 \times 10^{-09} \uparrow$ \\
\hline 19 & rs34342646 & 0.270 & PVRL2 & CSF assoc.* & $\mathrm{C}$ & Intron & $1.01 \times 10^{-08} \downarrow$ & $6.93 \times 10^{-06} \uparrow$ & $2.53 \times 10^{-05} \uparrow$ & $2.05 \times 10^{-09} \uparrow$ & $6.83 \times 10^{-10} \uparrow$ \\
\hline 19 & rs71352238 & 0.269 & TOММ40 & CSF assoc.* & $\mathrm{C}$ & Intergenic & $7.88 \times 10^{-09} \downarrow$ & $9.10 \times 10^{-07} \uparrow$ & $4.01 \times 10^{-06} \uparrow$ & $2.62 \times 10^{-10} \uparrow$ & $1.02 \times 10^{-10} \uparrow$ \\
\hline 19 & rs157580 & 0.264 & ТОММ40 & CSF assoc.* & C & Intron & $2.96 \times 10^{-04} \uparrow$ & $4.76 \times 10^{-02}$ & 0.0713 & $2.13 \times 10^{-03} \downarrow$ & $1.22 \times 10^{-03} \downarrow$ \\
\hline 19 & rs2075650 & 0.263 & TOMМ40 & CSF assoc.* & & Intron & $1.05 \times 10^{-09} \downarrow$ & $2.31 \times 10^{-06} \uparrow$ & $1.40 \times 10^{-05} \uparrow$ & $2.10 \times 10^{-10} \uparrow$ & $9.66 \times 10^{-11} \uparrow$ \\
\hline 19 & rs34404554 & 0.264 & TOMM40 & CSF assoc.* & & Intron & $1.57 \times 10^{-09} \downarrow$ & $2.73 \times 10^{-06} \uparrow$ & $1.37 \times 10^{-05} \uparrow$ & $2.88 \times 10^{-10} \uparrow$ & $1.12 \times 10^{-10} \uparrow$ \\
\hline 19 & rs11556505 & 0.264 & TOMМ40 & CSF assoc.* & C & Synonymous & $1.71 \times 10^{-09} \downarrow$ & $2.50 \times 10^{-06} \uparrow$ & $1.31 \times 10^{-05} \uparrow$ & $2.78 \times 10^{-10} \uparrow$ & $1.01 \times 10^{-10} \uparrow$ \\
\hline 19 & rs769449 & 0.295 & $A P O E$ & CSF assoc.* & $\mathrm{C}$ & Intron & $2.57 \times 10^{-14} \downarrow$ & $2.82 \times 10^{-09} \uparrow$ & $4.11 \times 10^{-06} \uparrow$ & $1.92 \times 10^{-15} \uparrow$ & $1.29 \times 10^{-13} \uparrow$ \\
\hline 19 & rs429358 & 0.340 & $A P O E$ & AD/CSF assoc.* & $\mathrm{C}$ & Intergenic & $2.03 \times 10^{-17} \downarrow$ & $1.40 \times 10^{-11} \uparrow$ & $3.18 \times 10^{-08} \uparrow$ & $1.85 \times 10^{-19} \uparrow$ & $5.89 \times 10^{-18} \uparrow$ \\
\hline 19 & rs439401 & 0.282 & LOC100129500 & CSF assoc.* & $\mathrm{C}$ & Intron & $1.43 \times 10^{-04} \uparrow$ & $3.82 \times 10^{-02} \downarrow$ & 0.3982 & $1.18 \times 10^{-03} \downarrow$ & $5.47 \times 10^{-03} \downarrow$ \\
\hline 20 & rs7274581 & 0.060 & CASS4 & AD assoc.* & A & Intron & 0.9363 & $4.79 \times 10^{-02} \downarrow$ & $1.01 \times 10^{-02} \downarrow$ & 0.1887 & 0.1184 \\
\hline
\end{tabular}

Chr., chromosome; dbSNP, single nucleotide polymorphism; MAF, minor allele frequency; nb, number; Alleles (minor/major); INPP5D, Inositol Polyphosphate-5-Phosphatase D; SNAR-I, small ILF3/NF90-associated RNA I; CD2AP, CD2 Associated protein; GLIS3, GLIS Family Zinc Finger 3; PVRL2, poliovirus receptor-related 2 (herpesvirus entry mediator B); TOMM40, translocase of outer mitochondrial membrane 40 homolog (yeast); APOE, apolipoprotein E; LOC100129500, hypothetical LOC100129500; CASS4, Cas Scaffolding Protein Family Member 4; AD assoc. *, top SNP previously found associated with AD; CSF assoc.*, top SNP previously found associated with CSF biomarkers (A $\beta_{1-42}, \mathrm{t}$-tau, and/or p-tau); AD/CSF assoc.* top SNP previously found associated with $\mathrm{AD}$ and with CSF biomarkers $\left(\mathrm{A} \beta_{1-42}\right.$, t-tau, and/or p-tau); $\uparrow$, association with higher levels of CSF biomarker; $\downarrow$, association with lower levels of CSF biomarker. Significance

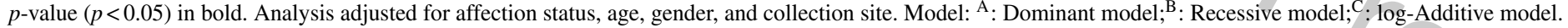

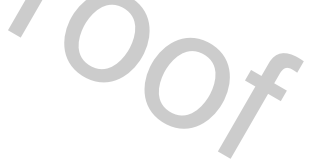




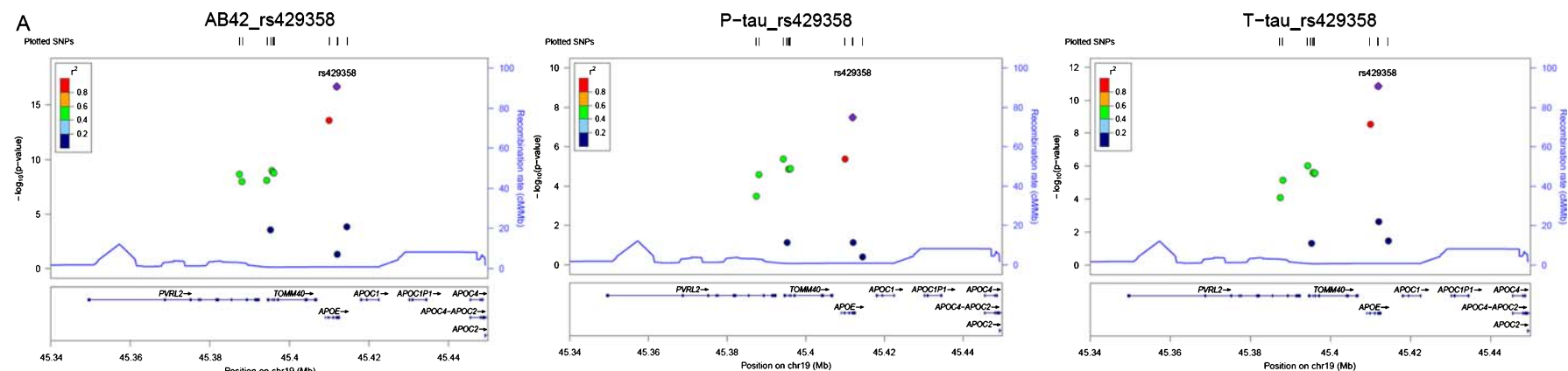

. 1. Regional plots for associations with CSF t-tau, p-tau, $A \beta_{1-42}$ and with ratios p-tau/A $\beta_{1-42}$ and $\mathrm{t}$-tau/A $\beta_{42}$. A) Plots are centered on the most significant SNP, rs 429358 within $A P O E$, along with the combined-analysis results for SNPs in the region surrounding it (typically $\pm 0.1 \mathrm{Mb}$ ). B) Plots are centered on the most significant SNP, rs 429358 within $A P O E$, along with the combined-analysis results for SNPs in the region surrounding it (typically $\pm 0.1 \mathrm{Mb}$ ). Symbols are colored according to the LD of the SNP with the top SNP. The light blue line represents the estimated recombination rate marked on the right-hand $y$-axis of each regional plot. Gene annotations are shown as dark blue lines (http://locuszoom.sph.umich.edu/locuszoom/). See also Supplementary Table 1 .

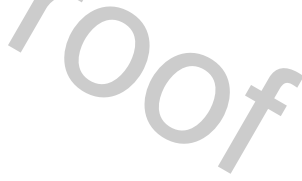


Table 3

Significant SNPs for $\mathrm{A} \beta_{1-42}, \mathrm{t}-\mathrm{tau}$, and p-tau levels, and with t-tau/A $\beta_{1-42}$ and p-tau/A $\beta_{1-42}$ ratios (adjusted for affection status, age, gender, collection site, and $A P O E$ genotype). Significance after Bonferroni adjustment (corrected $p<1.39 \times 10^{-3}$ )

\begin{tabular}{|c|c|c|c|c|c|c|c|c|c|c|c|}
\hline $\mathrm{Chr}$ & $\mathrm{dbSNP}$ & MAF & Gene & Reason for SNP Selection & Model & Location/SNP type & $\mathrm{A} \beta_{1-42}$ & $\mathrm{t}$-tau & p-tau & $\mathrm{t}$-tau/A $\beta_{1-42}$ & $\mathrm{p}-\operatorname{tau} / \mathrm{A} \beta_{1-42}$ \\
\hline 2 & rs 35349669 & 0.435 & INPP5D & AD assoc.* & B & Intron & 0.6483 & $3.20 \times 10^{-02} \downarrow$ & 0.3958 & 0.0523 & 0.3095 \\
\hline 3 & rs 1316356 & 0.396 & SNAR-I & CSF assoc.* & A & Intergenic & 0.4082 & $7.17 \times 10^{-03} \uparrow$ & $1.01 \times 10^{-02} \uparrow$ & 0.1637 & 0.3208 \\
\hline 3 & rs9877502 & 0.399 & SNAR-I & CSF assoc.* & A & Intergenic & 0.4645 & $1.16 \times 10^{-02} \uparrow$ & $1.97 \times 10^{-02} \uparrow$ & 0.1745 & 0.3379 \\
\hline 6 & rs9349407 & 0.280 & $C D 2 A P$ & AD assoc.* & $\mathrm{C}$ & Intron & 0.8520 & 0.0606 & 0.1620 & 0.2524 & 0.4068 \\
\hline 9 & rs514716 & 0.151 & GLIS3 & CSF assoc.* & A & Intron & 0.9809 & 0.0787 & 0.1011 & 0.1844 & 0.3812 \\
\hline 19 & rs 12972156 & 0.251 & PVRL2 & CSF assoc.* & $\mathrm{C}$ & Intron & 0.6220 & 0.7631 & 0.3913 & 0.9225 & 0.4180 \\
\hline 19 & rs 34342646 & 0.270 & PVRL2 & CSF assoc.* & $\mathrm{C}$ & Intron & 0.8508 & 0.6813 & 0.1105 & 0.7326 & 0.2041 \\
\hline 19 & rs71352238 & 0.269 & TOММ40 & CSF assoc.* & $\mathrm{C}$ & Intergenic & 0.8662 & 0.3599 & $3.62 \times 10^{-02} \uparrow$ & 0.4839 & 0.1123 \\
\hline 19 & rs 157580 & 0.264 & TOMM40 & CSF assoc.* & $\mathrm{C}$ & Intron & 0.6392 & 0.7307 & 0.8672 & 0.9011 & 0.7270 \\
\hline 19 & rs 2075650 & 0.263 & ТОММ40 & CSF assoc.* & $\mathrm{C}$ & Intron & 0.6791 & 0.6103 & 0.0977 & 0.6009 & 0.1596 \\
\hline 19 & rs34404554 & 0.264 & ТОММ40 & CSF assoc.* & C & Intron & 0.7389 & 0.6585 & 0.0992 & 0.6691 & 0.1778 \\
\hline 19 & rs11556505 & 0.264 & ТОММ40 & CSF assoc.* & & Synonymous & 0.7934 & 0.6599 & 0.0964 & 0.6985 & 0.1735 \\
\hline 19 & rs769449 & 0.295 & $A P O E$ & CSF assoc.* & $\mathrm{C}$ & Intron & 0.3706 & 0.2731 & 0.1632 & 0,2556 & 0.1987 \\
\hline 19 & rs429358 & 0.340 & $A P O E$ & $\mathrm{AD} / \mathrm{CSF}$ assoc.* & $\mathrm{C}$ & Intergenic & 0.0877 & $8.85 \times 10^{-03} \uparrow$ & $3.42 \times 10^{-05} \uparrow$ & $8.27 \times 10^{-03} \uparrow$ & $2.40 \times 10^{-04} \uparrow$ \\
\hline 19 & rs439401 & 0.282 & LOC100129500 & CSF assoc.* & $\mathrm{C}$ & Intron & 0.6585 & 0.6680 & 0.7921 & 0.7731 & 0.5624 \\
\hline 20 & rs7274581 & 0.060 & CASS4 & AD assoc.* & A & Intron & 0.9953 & $3.43 \times 10^{-02} \downarrow$ & $5.48 \times 10^{-03} \downarrow$ & 0.1251 & 0.0873 \\
\hline
\end{tabular}

Chr., chromosome; dbSNP, single nucleotide polymorphism; MAF, minor allele frequency; nb, number; Alleles (minor/major); INPP5D, Inositol Polyphosphate-5-Phosphatase D; SNAR-I, small ILF3/NF90-associated RNA I; CD2AP, CD2 Associated protein; GLIS3, GLIS Family Zinc Finger 3; PVRL2, poliovirus receptor-related 2 (herpesvirus entry mediator B); TOMM40, translocase of outer mitochondrial membrane 40 homolog (yeast); APOE, apolipoprotein E; LOC100129500, hypothetical LOC100129500; CASS4, Cas Scaffolding Protein Family Member 4; AD assoc.*, top SNP previously found associated with AD; CSF assoc.*, top SNP previously found associated with CSF biomarkers (A $\beta_{1-42}$, t-tau, and/or p-tau); AD/CSF assoc.*, top SNP previously found associated with $\mathrm{AD}$ and with CSF biomarkers $\left(\mathrm{A} \beta_{1-42}\right.$, t-tau, and/or p-tau); $\uparrow$, association with higher levels of CSF biomarker; $\downarrow$, association with lower levels of CSF biomarker. Significance $p$-value $(p<0.05)$ in bold. Analysis adjusted for affection status, age, gender, collection site, and APOE genotype. Model: ${ }^{\mathrm{A}}$ : Dominant model; ${ }^{\mathrm{B}}$ : Recessive model; ${ }^{\mathrm{C}}$ : log-Additive model.

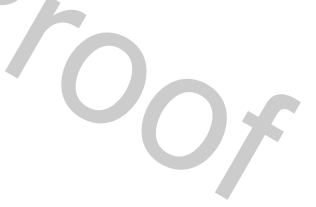


important role in the clinical practice, where these have been increasingly used, improving early and differential diagnosis of AD [22].

Our study intends to strengthen the main findings in AD CSF biomarkers quantitative genetics, clarifying previous inconsistencies and reinforcing the implication of specific underpinning mechanisms in AD. Here, we disclose novel associations between $\mathrm{AD}$ genetic risk variants and CSF biomarkers that can contribute to mechanistic insights for AD pathogenesis and also provide valuable information for newly potential underlying biological mechanisms.

Our top findings for significant association were verified within nine genes: APOE, TOMM40, LOC100129500, PVRL2, SNAR-I, GLIS3, CASS4, INPP5D, and CD2AP.

$A P O E$, located at chromosome $19 \mathrm{q} 13.2$ is the most well characterized genetic risk factor for $\mathrm{AD}$ and is highly expressed in liver and brain playing an important role in mobilization and redistribution of cholesterol [23]. It is known that $A P O E$ binds to $A \beta$ influencing the clearance of soluble $A \beta$ and $A \beta$ aggregation $[14,24]$, which explains a large proportion of the variance in $A \beta$ levels, with no other locus showing similarly large effects. More recently evidence started to accumulate related to the influence of $A P O E$ on tau pathology by an $\mathrm{A} \beta$-independent mechanism $[11,14,16]$. In our findings, rs429358 (which defines the $\varepsilon 4$ allele) is strongly correlated with the CSF biomarkers, $A \beta_{1-42}$, t-tau, and p-tau and also with the ratios (t-tau/A $\beta_{1-42}$ and p-tau/A $\beta_{1-42}$ ) along with rs769449, both associated with lower CSF $A \beta_{1-42}$ and higher levels of tau, suggestive of an increased risk for the disorder. In turn, rs7412 (which defines $\varepsilon 2$ allele) is not associated with any CSF biomarker (data not shown). These results replicate the findings of Cruchaga et al. and of Deming et al., both reported rs769449 as the most significantly associated $A P O E$ SNP being highly associated with CSF A $\beta_{1-42}$, t-tau, and p-tau markers [11, 16]. Additionally, it replicates the significant association of rs429538 in the GWAS from the Alzheimer's Disease Neuroimaging Initiative (ADNI) cohort, which investigated the influence of genetic variation on CSF biomarkers in 374 non-Hispanic Caucasian participants, showing that rs429538 is associated with CSF $\mathrm{A} \beta_{1-42}$, p-tau, $\mathrm{p}$-tau $/ \mathrm{A} \beta_{1-42}$ and $\mathrm{t}-\mathrm{tau} / \mathrm{A} \beta_{1-42}$ ratio $\left(p<1 \times 10^{-6}\right.$ in all biomarkers) [14].

Apart of $A P O E$, the strongest associations were shown with TOMM40 and PVRL2. TOMM40, a nearby gene (positioned about $15 \mathrm{~kb}$ upstream) of $A P O E$, is a transporter of proteins across the mitochondrial membrane, and a sortilin-related receptor, which functions to partition amyloid- $\beta$ protein precursor (A $\beta P P)$ away from $\beta$-secretase and $\gamma$-secretase. In our findings, TOMM40 variants were significantly associated with lower CSF $A \beta_{1-42}$ levels and higher tau levels, as well as with higher ratios of $p$-tau/A $\beta_{1-42}$ and t-tau/A $\beta_{1-42}$, suggesting a link between these SNPs and AD risk. The main findings in this gene are also consistent with the report by Cruchaga et al. and Kim et al. showing TOMM40 as a region correlated with $\operatorname{CSF} A \beta_{1-42}$ and t-tau levels, and with the ratios $\mathrm{p}-\operatorname{tau}_{181} / \mathrm{A} \beta_{1-42}$ and $\mathrm{t}-$ tau/A $\beta_{1-42}[11,14]$. TOMM40 has been recognized as a genetic risk factor for $\mathrm{AD}$ [25], namely through the association of the intronic SNP rs2075650, which in turn is known to be in tight linkage disequilibrium with the APOE locus [26]. More recently, a study from Zeitlow et al. supported the hypothesis that deregulation of TOMM40 expression alters mitochondrial function, leading to pathophysiological consequences, including neurological defects [27]. Their data suggests that high expression levels of TOMM40 may be protective of mitochondrial function and could eventually be an interesting target for therapeutic intervention in $\mathrm{AD}$ [27]. The gene $P V R L 2$, encodes the poliovirus receptor 2, a member of the immunoglobulin superfamily expressed in diverse cell tissues, including neurons and is recognized to be a risk factor contributing to $\mathrm{AD}$ pathogenesis [11]. In our study, both rs12972156 and rs34342646 were the most significantly associated with lower CSF $A \beta_{1-42}$ and higher $t$-tau levels, suggestive of an influence on increased risk for AD and replicating the GWAS results of Cruchaga et al. [11].

LOC100129500 is located in a region which overlaps $A P O E$ and $A P O C 1$ and has been associated with AD [28]. From the tested SNPs, rs439401 showed an association with higher CSF $A \beta_{1-42}$ levels and with lower $\mathrm{t}$-tau levels, replicating the associations found by Kim et al., in the recent GWAS of CSF biomarkers $\left(p<1 \times 10^{-6}\right)[14]$.

SNAR-I is highly expressed in brain and is involved in neuronal synaptogenesis [11]. The SNPs rs1316356 and rs9877502 were associated with higher CSF t-tau and p-tau levels, but not with $A \beta_{1-42}$. These findings are in line with the results previously reported where SNAR-I was found as a novel locus associated with tau levels and as genetic variants that influence risk for $\mathrm{AD}$ via tau-dependent mechanism [11].

The gene GLIS3 is also highly expressed in the brain and has been implicated in diabetes mellitus 
pathogenesis [23]. In our study, rs9349407 was associated with increased CSF t-tau levels, supporting previous data [11].

A new association was identified on chromosome 20q13.31 within CASS4 (encoding Cas scaffolding protein family member 4 ). SNP rs7274581 that was found to be an $\mathrm{AD}$ protective variant in the largest meta-analysis to date, with 74,046 individuals [10], in our study was associated with decreased t-tau and p-tau levels and thus in line with the suggested protective effect. The function of the encoded protein is not fully known, but it seems to be involved in cytoskeletal function and axonal transport, and was also implicated in $\mathrm{A} \beta \mathrm{PP}$ and tau metabolism [10, 29].

Another novel association was found for INPP5D in chromosome 2 (encoding inositol polyphosphate5-phosphatase). INPP5D is expressed at low levels in the brain, but the encoded protein has been shown to interact with $C D 2 A P$, whose corresponding gene is one of the $\mathrm{AD}$ genes previously identified by GWAS, and to modulate, along with GRB2, metabolism of A $\beta P P$ [10]. Additionally, it has been demonstrated that INPP5D could regulate the gene expression and post-translational modification of proteins [10], as well as microglial and myeloid cell function [3]. The SNP rs35349669 seems to decrease t-tau levels possibly having a protective role. The INPP5D locus was also recently reported to be associated with p-tau levels, in a recent large genome-wide association study [16].

Another novel association was detected on chromosome 6 at $C D 2 A P$, where SNP rs9349407 was associated with increased t-tau and presumably with a deleterious effect on AD. This gene encodes a scaffolding protein involved in cytoskeletal reorganization and intracellular trafficking [30]. SNPs within 6q12 locus have been found associated with increased AD risk in several GWAS [8-10]. Additionally, CD2AP (rs9349407) has also been found associated with neuritic plaque burden in AD brains [31], thus further supporting a pathogenic role for $C D 2 A P$.

SNAR-I, GLIS3, CASS4, INPP5D, and CD2AP genetic variants influence CSF tau biomarkers, but not the CSF amyloid biomarker $A \beta_{1-42}$. This suggests that they might specifically regulate tau aggregation, processing or clearance other than interfering with A $\beta P P$ metabolism. As far as we know from their function, reviewed above, they appear to be involved in cytoskeletal reorganization and intracellular trafficking, where they would cooperate or interfere with the tau-dependent processes of microtubule assembly.

We noted a number of changes in the strength of correlation when we corrected for APOE. TOMM40 was no longer associated with CSF $A \beta_{42}$. This confirms previous findings that TOMM4O is in strong linkage disequilibrium with $A P O E$. The effect of LOC100129500 and PVRL2 on $\mathrm{A} \beta_{42}$ and CD2AP, GLIS3, and PVRL2 on tau also became nonsignificant. This suggests that the effect was not independent of APOE. Regarding INPP5, SNAR-I, and CASS4, we found no or minor changes on correlation with CSF markers after $A P O E$ correction implying a largely independent effect from $A P O E$.

In conclusion, our results emphasize the usefulness of exploring $\mathrm{AD}$ associated genetic variants and relevant endophenotypes, reinforcing the involvement of specific genes in AD pathogenesis through biologic mechanisms that directly alter CSF levels of $\mathrm{A} \beta_{1-42}, \mathrm{p}$-tau, and $\mathrm{t}$-tau. In particular, the finding of novel genetic variants that specifically influence CSF tau biomarkers may point out new mechanisms and pathways, largely independent of amyloid processing, which specifically regulate tau aggregation, processing or clearance, eventually suggesting innovative targets for the treatment of $\mathrm{AD}$.

\section{ACKNOWLEDGMENTS}

The authors thank contributors, including the Alzheimer's Disease Research Centers that collected samples used in this study, as well as patients and their families, whose help and participation made this work possible.

This work is part of the BIOMARKAPD project within the EU Joint Programme for Neurodegenerative Disease Research (JPND). This project was funded through the following funding organizations under the aegis of JPND - http://www.jpnd.eu: Portugal: Fundação para a Ciência e Tecnologia (FCT) (JPND/0005/2011 project); Finland: The Academy of Finland AoF (307866); Spain: Instituto de Salud Carlos III (ISCII); Italy: Italian Ministry of Health (Ricerca Corrente); The Netherlands: ZonMW - The Netherlands Organization for Health Research and Development grant number 629000002; Germany: German Bundesministerium für Bildung und Forschung (BMBF); Denmark: Innovation Fund Denmark (grant no 0603-00470B); Greece: Ministry of Education, Life Long Learning and Religious Affairs, General Secretariat for 
Research and Technology. This research was also supported by the Fundação para a Ciência e a Tecnologia (FCT) (SFRH/BPD/29354/2006 to M.M.); by the Sigrid Jusélius Foundation and the Strategic Neuroscience Funding of the University of Eastern Finland; and by the European Union (NSRF 20072013) and Greek national funds.

Authors' disclosures available online (https:// www.j-alz.com/manuscript-disclosures/18-0512r1).

\section{SUPPLEMENTARY MATERIAL}

The supplementary material is available in the electronic version of this article: http://dx.doi. org/10.3233/JAD-180512.

\section{REFERENCES}

[1] O'Brien RJ, Wong PC (2011) Amyloid precursor protein processing and Alzheimer's disease. Annu Rev Neurosci 34, 185-204.

[2] Fagan AM, Mintun MA, Mach RH, Lee SY, Dence CS, Shah AR, LaRossa GN, Spinner ML, Klunk WE, Mathis CA, DeKosky ST, Morris JC, Holtzman DM (2006) Inverse relation between in vivo amyloid imaging load and cerebrospinal fluid Abeta;42 in humans. Ann Neurol 59, 512-519.

[3] Blennow K, de Leon MJ, Zetterberg H (2006) Alzheimer's disease. Lancet 368, 387-403.

[4] de Leon MJ, DeSanti S, Zinkowski R, Mehta PD, Pratico D, Segal S, Clark C, Kerkman D, DeBernardis J, Li J, Lair L, Reisberg B, Tsui W, Rusinek H (2004) MRI and CSF studies in the early diagnosis of Alzheimer's disease. J Intern Med 256, 205-223.

[5] Maddalena A, Papassotiropoulos A, Müller-Tillmanns B, Jung HH, Hegi T, Nitsch RM, Hock C (2003) Biochemical diagnosis of Alzheimer disease by measuring the cerebrospinal fluid ratio of phosphorylated tau protein to beta-amyloid peptide42. Arch Neurol 60, 1202-1206.

[6] Lambert JC, Amouyel P (2011) Genetics of Alzheimer's disease: New evidences for an old hypothesis? Curr Opin Genet Dev 21, 295-301.

[7] Harold D, Abraham R, Hollingworth P, Sims R, Gerrish A, Hamshere ML, Pahwa JS, Moskvina V, Dowzell K, Williams A, Jones N, Thomas C, Stretton A, Morgan AR, Lovestone S, Powell J, Proitsi P, Lupton MK, Brayne C, Rubinsztein DC, Gill M, Lawlor B, Lynch A, Morgan K, Brown KS, Passmore PA, Craig D, McGuinness B, Todd S, Holmes C, Mann D, Smith AD, Love S, Kehoe PG, Hardy J, Mead S, Fox N, Rossor M, Collinge J, Maier W, Jessen F, Schurmann B, van den BH, Heuser I, Kornhuber J, Wiltfang J, Dichgans M, Frolich L, Hampel H, Hull M, Rujescu D, Goate AM, Kauwe JS, Cruchaga C, Nowotny P, Morris JC, Mayo K, Sleegers K, Bettens K, Engelborghs S, De Deyn PP, Van BC, Livingston G, Bass NJ, Gurling H, McQuillin A, Gwilliam R, Deloukas P, Al-Chalabi A, Shaw CE, Tsolaki M, Singleton AB, Guerreiro R, Muhleisen TW, Nothen MM, Moebus S, Jockel KH, Klopp N, Wichmann HE, Carrasquillo MM, Pankratz VS, Younkin SG, Holmans PA, O'Donovan M, Owen MJ, Williams J
(2009) Genome-wide association study identifies variants at CLU and PICALM associated with Alzheimer's disease. Nat Genet 41, 1088-1093.

[8] Naj AC, Jun G, Beecham GW, Wang L-S, Vardarajan BN, Buros J, Gallins PJ, Buxbaum JD, Jarvik GP, Crane PK, Larson EB, Bird TD, Boeve BF, Graff-Radford NR, De Jager PL, Evans D, Schneider JA, Carrasquillo MM, ErtekinTaner N, Younkin SG, Cruchaga C, Kauwe JSK, Nowotny P, Kramer P, Hardy J, Huentelman MJ, Myers AJ, Barmada MM, Demirci FY, Baldwin CT, Green RC, Rogaeva E, St George-Hyslop P, Arnold SE, Barber R, Beach T, Bigio EH, Bowen JD, Boxer A, Burke JR, Cairns NJ, Carlson CS, Carney RM, Carroll SL, Chui HC, Clark DG, Corneveaux J, Cotman CW, Cummings JL, DeCarli C, DeKosky ST, Diaz-Arrastia R, Dick M, Dickson DW, Ellis WG, Faber KM, Fallon KB, Farlow MR, Ferris S, Frosch MP, Galasko DR, Ganguli M, Gearing M, Geschwind DH, Ghetti B, Gilbert JR, Gilman S, Giordani B, Glass JD, Growdon JH, Hamilton RL, Harrell LE, Head E, Honig LS, Hulette CM, Hyman BT, Jicha GA, Jin L-W, Johnson N, Karlawish J, Karydas A, Kaye JA, Kim R, Koo EH, Kowall NW, Lah JJ, Levey AI, Lieberman AP, Lopez OL, Mack WJ, Marson DC, Martiniuk F, Mash DC, Masliah E, McCormick WC, McCurry SM, McDavid AN, McKee AC, Mesulam M, Miller BL, Miller CA, Miller JW, Parisi JE, Perl DP, Peskind E, Petersen RC, Poon WW, Quinn JF, Rajbhandary RA, Raskind M, Reisberg B, Ringman JM, Roberson ED, Rosenberg RN, Sano M, Schneider LS, Seeley W, Shelanski ML, Slifer MA, Smith CD, Sonnen JA, Spina S, Stern RA, Tanzi RE, Trojanowski JQ, Troncoso JC, Van Deerlin VM, Vinters H V., Vonsattel JP, Weintraub S, Welsh-Bohmer KA, Williamson J, Woltjer RL, Cantwell LB, Dombroski BA, Beekly D, Lunetta KL, Martin ER, Kamboh MI, Saykin AJ, Reiman EM, Bennett DA, Morris JC, Montine TJ, Goate AM, Blacker D, Tsuang DW, Hakonarson H, Kukull WA, Foroud TM, Haines JL, Mayeux R, Pericak-Vance MA, Farrer LA, Schellenberg GD (2011) Common variants at MS4A4/MS4A6E, CD2AP, CD33 and EPHA1 are associated with late-onset Alzheimer's disease. Nat Genet 43, 436-441.

[9] Hollingworth P, Harold D, Sims R, Gerrish A, Lambert JC, Carrasquillo MM, Abraham R, Hamshere ML, Pahwa JS, Moskvina V, Dowzell K, Jones N, Stretton A, Thomas C, Richards A, Ivanov D, Widdowson C, Chapman J, Lovestone S, Powell J, Proitsi P, Lupton MK, Brayne C, Rubinsztein DC, Gill M, Lawlor B, Lynch A, Brown KS, Passmore PA, Craig D, McGuinness B, Todd S, Holmes C, Mann D, Smith AD, Beaumont H, Warden D, Wilcock G, Love S, Kehoe PG, Hooper NM, Vardy ERLC, Hardy J, Mead S, Fox NC, Rossor M, Collinge J, Maier W, Jessen F, Rüther E, Schürmann B, Heun R, Kölsch H, van den Bussche H, Heuser I, Kornhuber J, Wiltfang J, Dichgans M, Frölich L, Hampel H, Gallacher J, Hüll M, Rujescu D, Giegling I, Goate AM, Kauwe JSK, Cruchaga C, Nowotny P, Morris JC, Mayo K, Sleegers K, Bettens K, Engelborghs S, De Deyn PP, Van Broeckhoven C, Livingston G, Bass NJ, Gurling H, McQuillin A, Gwilliam R, Deloukas P, AlChalabi A, Shaw CE, Tsolaki M, Singleton AB, Guerreiro R, Mühleisen TW, Nöthen MM, Moebus S, Jöckel K-H, Klopp N, Wichmann H-E, Pankratz VS, Sando SB, Aasly JO, Barcikowska M, Wszolek ZK, Dickson DW, GraffRadford NR, Petersen RC, van Duijn CM, Breteler MMB, Ikram MA, DeStefano AL, Fitzpatrick AL, Lopez O, Launer LJ, Seshadri S, Berr C, Campion D, Epelbaum J, Dartigues J-F, Tzourio C, Alpérovitch A, Lathrop M, Feulner TM, 
Friedrich P, Riehle C, Krawczak M, Schreiber S, Mayhaus M, Nicolhaus S, Wagenpfeil S, Steinberg S, Stefansson H, Stefansson K, Snaedal J, Björnsson S, Jonsson P V, Chouraki V, Genier-Boley B, Hiltunen M, Soininen H, Combarros O, Zelenika D, Delepine M, Bullido MJ, Pasquier F, Mateo I, Frank-Garcia A, Porcellini E, Hanon O, Coto E, Alvarez V, Bosco P, Siciliano G, Mancuso M, Panza F, Solfrizzi V, Nacmias B, Sorbi S, Bossú P, Piccardi P, Arosio B, Annoni G, Seripa D, Pilotto A, Scarpini E, Galimberti D, Brice A, Hannequin D, Licastro F, Jones L, Holmans PA, Jonsson T, Riemenschneider M, Morgan K, Younkin SG, Owen MJ, O'Donovan M, Amouyel P, Williams J (2011) Common variants at ABCA7, MS4A6A/MS4A4E, EPHA1, CD33 and CD2AP are associated with Alzheimer's disease. Nat Genet 43, 429-35.

[10] Lambert JC, Ibrahim-Verbaas CA, Harold D, Naj AC, Sims R, Bellenguez C, DeStafano AL, Bis JC, Beecham GW, Grenier-Boley B, Russo G, Thorton-Wells TA, Jones N, Smith AV, Chouraki V, Thomas C, Ikram MA, Zelenika D, Vardarajan BN, Kamatani Y, Lin CF, Gerrish A, Schmidt H, Kunkle B, Dunstan ML, Ruiz A, Bihoreau MT, Choi SH, Reitz C, Pasquier F, Cruchaga C, Craig D, Amin N, Berr C, Lopez OL, De Jager PL, Deramecourt V, Johnston JA, Evans D, Lovestone S, Letenneur L, Morón FJ, Rubinsztein DC, Eiriksdottir G, Sleegers K, Goate AM, Fiévet N, Huentelman MW, Gill M, Brown K, Kamboh MI, Keller L, Barberger-Gateau P, McGuiness B, Larson EB, Green R, Myers AJ, Dufouil C, Todd S, Wallon D, Love S, Rogaeva E, Gallacher J, St George-Hyslop P, Clarimon J, Lleo A, Bayer A, Tsuang DW, Yu L, Tsolaki M, Bossú P, Spalletta G, Proitsi P, Collinge J, Sorbi S, Sanchez-Garcia F, Fox NC, Hardy J, Deniz Naranjo MC, Bosco P, Clarke R, Brayne C, Galimberti D, Mancuso M, Matthews F, Moebus S, Mecocci P, Del Zompo M, Maier W, Hampel H, Pilotto A, Bullido M, Panza F, Caffarra P, Nacmias B, Gilbert JR, Mayhaus M, Lannefelt L, Hakonarson H, Pichler S, Carrasquillo MM, Ingelsson M, Beekly D, Alvarez V, Zou F, Valladares O, Younkin SG, Coto E, Hamilton-Nelson KL, Gu W, Razquin C, Pastor P, Mateo I, Owen MJ, Faber KM, Jonsson PV, Combarros O, O'Donovan MC, Cantwell LB, Soininen H, Blacker D, Mead S, Mosley TH, Bennett DA, Harris TB, Fratiglioni L, Holmes C, de Bruijn RF, Passmore P, Montine TJ, Bettens K, Rotter JI, Brice A, Morgan K, Foroud TM, Kukull WA, Hannequin D, Powell JF, Nalls MA, Ritchie K, Lunetta KL, Kauwe JS, Boerwinkle E, Riemenschneider M, Boada M, Hiltuenen M, Martin ER, Schmidt R, Rujescu D, Wang LS, Dartigues JF, Mayeux R, Tzourio C, Hofman A, Nöthen MM, Graff C, Psaty BM, Jones L, Haines JL, Holmans PA, Lathrop M, Pericak-Vance MA, Launer LJ, Farrer LA, van Duijn CM, Van Broeckhoven C, Moskvina V, Seshadri S, Williams J, Schellenberg GD, Amouyel P (2013) Meta-analysis of 74,046 individuals identifies 11 new susceptibility loci for Alzheimer's disease. Nat Genet 45, 1452-1458.

[11] Cruchaga C, Kauwe JSK, Harari O, Jin SC, Cai Y, Karch CM, Benitez Ba., Jeng AT, Skorupa T, Carrell D, Bertelsen S, Bailey M, McKean D, Shulman JM, De Jager PL, Chibnik L, Bennett Da., Arnold SE, Harold D, Sims R, Gerrish A, Williams J, Van Deerlin VM, Lee VMY, Shaw LM, Trojanowski JQ, Haines JL, Mayeux R, PericakVance Ma., Farrer La., Schellenberg GD, Peskind ER, Galasko D, Fagan AM, Holtzman DM, Morris JC, Goate AM (2013) GWAS of cerebrospinal fluid tau levels identifies risk variants for alzheimer's disease. Neuron 78, 256-268.
[12] Kauwe JSK, Wang J, Mayo K, Morris JC, Fagan AM, Holtzman DM, Goate AM (2009) Alzheimer's disease risk variants show association with cerebrospinal fluid amyloid beta. Neurogenetics 10, 13-17.

[13] Cruchaga C, Kauwe JSK, Mayo K, Spiegel N, Cruchaga C, Kauwe JSK, Mayo K, Spiegel N, Bertelsen S, Nowotny P, Shah AR, Abraham R, Hollingworth P, Harold D, Owen MM, Williams J, Lovestone S, Peskind ER, Li G, Leverenz JB, Galasko D, Morris JC, Fagan AM, Holtzman DM, Goate AM (2010) SNPs associated with cerebrospinal fluid Phospho-tau levels influence rate of decline in alzheimer's disease. PLoS Genet 6, 1-10.

[14] Kim S, Swaminathan S, Shen L, Risacher SL, Nho K, Foroud T, Shaw LM, Trojanowski JQ, Potkin SG, Huentelman MJ, Craig DW, DeChairo BM, Aisen PS, Petersen RC, Weiner MW, Saykin AJ (2011) Genome-wide association study of CSF biomarkers Abeta1-42, t-tau, and p-tau181p in the ADNI cohort. Neurology 76, 69-79.

[15] Elias-Sonnenschein LS, Helisalmi S, Natunen T, Hall A, Paajanen T, Herukka SK, Laitinen M, Remes AM, Koivisto AM, Mattila KM, Lehtimäki T, Verhey FRJ, Visser PJ, Soininen H, Hiltunen M (2013) Genetic loci associated with Alzheimer's disease and cerebrospinal fluid biomarkers in a Finnish case-control cohort. PLoS One 8, e59676.

[16] Deming Y, Li ZR, Kapoor M, Harari O, Del-Aguila JL, Black K, Carrell D, Cai YF, Fernandez M V, Budde J, Ma SM, Saef B, Howells B, Huang KL, Bertelsen S, Fagan AM, Holtzman DM, Morris JC, Kim S, Saykin AJ, De Jager PL, Albert M, Moghekar A, O'Brien R, Riemenschneider M, Petersen RC, Blennow K, Zetterberg H, Minthon L, Van Deerlin VM, Lee VMY, Shaw LM, Trojanowski JQ, Schellenberg G, Haines JL, Mayeux R, Pericak-Vance MA, Farrer LA, Peskind ER, Li G, Di Narzo AF; Alzheimer's Disease Neuroimaging Initiative (ADNI); Alzheimer Disease Genetic Consortium (ADGC), Kauwe JSK, Goate AM, Cruchaga C (2017) Genome-wide association study identifies four novel loci associated with Alzheimer's endophenotypes and disease modifiers. Acta Neuropathol 133, 839-856.

[17] Han M-R, Schellenberg GD, Wang L-S (2010) Genomewide association reveals genetic effects on human $A \beta 42$ and $\tau$ protein levels in cerebrospinal fluids: A case control study. BMC Neurol 10, 90.

[18] McKhann G, Drachman D, Folstein M, Katzman R, Price D, Stadlan EM (1984) Clinical diagnosis of Alzheimer's disease: Report of the NINCDS-ADRDA Work Group under the auspices of Department of Health and Human Services Task Force on Alzheimer's Disease. Neurology 34, 939-944.

[19] McKhann G, Knopman DS, Chertkow H, Hymann B, Jack CR, Kawas C, Klunk W, Koroshetz W, Manly J, Mayeux R, Mohs R, Morris J, Rossor M, Scheltens P, Carrillo M, Weintrub S, Phelphs C (2011) The diagnosis of dementia due to Alzheimer's disease: Recommendations from the National Institute on Aging- Alzheimer's Association workgroups on diagnostic guidelines for Alzheimer's disease. Alzheimers Dement 7, 263-269.

[20] Bertram L, McQueen MB, Mullin K, Blacker D, Tanzi RE (2007) Systematic meta-analyses of Alzheimer disease genetic association studies: The AlzGene database. Nat Genet 39, 17-23.

[21] González JR, Armengol L, Solé X, Guinó E, Mercader JM, Estivill X, Moreno V (2007) SNPassoc: An R package to perform whole genome association studies. Bioinformatics 23, 644-645. 
[22] Herukka S-K, Simonsen AH, Andreasen N, Baldeiras I, Bjerke M, Blennow K, Engelborghs S, Frisoni GB, Gabryelewicz T, Galluzzi S, Handels R, Kramberger MG, Kulczyńska A, Molinuevo JL, Mroczko B, Nordberg A, Oliveira CR, Otto M, Rinne JO, Rot U, Saka E, Soininen H, Struyfs H, Suardi S, Visser PJ, Winblad B, Zetterberg H, Waldemar G (2017) Recommendations for cerebrospinal fluid Alzheimer's disease biomarkers in the diagnostic evaluation of mild cognitive impairment. Alzheimers Dement 13, 285-295.

[23] Bertram L, Tanzi RE (2009) Genome-wide association studies in Alzheimer's disease. Hum Mol Genet 18, 137-145.

[24] Castellano JM, Kim J, Stewart FR, Jiang H, DeMattos RB, Patterson BW, Fagan AM, Morris JC, Mawuenyega KG, Cruchaga C, Goate AM, Bales KR, Paul SM, Bateman RJ, Holtzman DM (2011) Human apoE isoforms differentially regulate brain amyloid- $\beta$ peptide clearance. Sci Transl Med 3, 89ra57.

[25] Roses AD, Lutz MW, Amrine-Madsen H, Saunders AM, Crenshaw DG, Sundseth SS, Huentelman MJ, Welsh-Bohmer KA, Reiman EM (2010) A TOMM40 variable-length polymorphism predicts the age of late-onset Alzheimer's disease. Pharmacogenomics J 10, 375-384.

[26] Jun G, Vardarajan BN, Buros J, Yu C-E, Hawk MV, Dombroski BA, Crane PK, Larson EB, Mayeux R, Haines JL, Lunetta KL, Pericak-Vance MA, Schellenberg GD, Farrer LA (2012) Comprehensive search for Alzheimer disease susceptibility loci in the APOE region. Arch Neurol 69, 1270-1279.
[27] Zeitlow K, Charlambous L, Ng I, Gagrani S, Mihovilovic M, Luo S, Rock DL, Saunders A, Roses AD, Gottschalk WK (2017) The biological foundation of the genetic association of TOMM40 with late-onset Alzheimer's disease. Biochim Biophys Acta 1863, 2973-2986.

[28] Abraham R, Moskvina V, Sims R, Hollingworth P, Morgan A, Georgieva L, Dowzell K, Cichon S, Hillmer AM, O'Donovan MC, Williams J, Owen MJ, Kirov G (2008) A genome-wide association study for late-onset Alzheimer's disease using DNA pooling. BMC Med Genomics 1, 44.

[29] Karch CM, Goate AM (2014) Alzheimer's disease risk genes and mechanisms of disease pathogenesis. Biol Psychiatry 77, 43-51.

[30] Dustin ML, Olszowy MW, Holdorf AD, Li J, Bromley S, Desai N, Widder P, Rosenberger F, Van Der Merwe PA, Allen PM, Shaw AS (1998) A novel adaptor protein orchestrates receptor patterning and cytoskeletal polarity in T-cell contacts. Cell 94, 667-677.

[31] Shulman JM, Chen K, Keenan BT, Chibnik LB, Fleisher A, Thiyyagura P, Roontiva A, McCabe C, Patsopoulos NA, Corneveaux JJ, Yu L, Huentelman MJ, Evans DA, Schneider JA, Reiman EM, De Jager PL, Bennett DA (2013) Genetic susceptibility for Alzheimer disease neuritic plaque pathology. JAMA Neurol 70, 1150-1157. 